\title{
Sensory evaluation and acceptability of goat milk in Odeda Local Government Area of Ogun state
}

\author{
${ }^{* 1}$ Adewumi, O. O., ${ }^{2}$ Irhekore, O. T., ${ }^{1}$ Ogundipe, T. G., ${ }^{3}$ Tona, G. O. and ${ }^{1}$ Oso, O. A. \\ ${ }^{\prime}$ Department of Animal Production and Health, Federal University of Agriculture, \\ Abeokuta, Ogun State \\ ${ }^{2}$ AMREC, Federal University of Agriculture, Abeokuta, Ogun State \\ ${ }^{3}$ Department of Animal Production and Health, \\ Ladoke Akintola University of Technology \\ *Corresponding author: E-mail: badewumi2003@yahoo.com
}

\section{Abstract}

This study was conducted to assess the sensory characteristics and acceptability of goat milk in Odeda Local Government Area of Ogun State. A total of seventy respondents were selected randomly. Milk collected from lactating West African Dwarf goats was pasteurized at a temperature of $74^{\circ} \mathrm{C}$ for five minutes, cooled, packaged in small polythene and sealed with machine and refrigerated. The milk was taken to various settlements in Odeda Local Government of Ogun state for sensory evaluation. Majority of the respondents were students $54.3 \%$ only a few $12.9 \%$ were traders with a high percentage between the ages of 21-30. Also, $67.1 \%$ and $70.0 \%$ of the respondents were Christian and Yorubas, respectively. Moreover, $65.7 \%$ of respondents were married, while $34.3 \%$ were unmarried. The married had a family size of $\leq 2$. Majority of the respondents (88.8\%) had tertiary education. The small number of respondents $37.1 \%$ involved in ruminant production had only 2 years ruminant farming experience and kept fewer than 5 goats. About $60 \%$ of the respondent consumed milk on weekly basis while 6\% consumed milk on daily. It was observed that 100\% of the respondents preferred cow milk despite the fact that $78.6 \%$ of the respondents were aware of goat milk consumption. The taste, colour, odour and flavor of goat milk were rated as Very good by 55.7\%, 37.1\%, 41.4\% and 41.4\% of respondents respectively. Majority of the respondents had a favourable disposition towards the taste (75.5\%), colour (62.9\%), odour $(80.0 \%)$ and flavour (61.4\%) when compared with other milk products in the market. Thus, goat milkt could be taken as alternative to cow milk without any detrimental effect It then become imperative for this positive perception to be explored by the government and other relevant development agencies so as to increase food supply to alleviate protein deficiency and therebyimproved the economy.

Keywords: Sensory, goat milk, consumption, settlements and respondents

\section{Introduction}

Goat milk is a complete food, rich in proteins, vitamins, minerals, and small fat molecules, which makes it highly digestible compared with milk from other animal species. Goat milk is considered a good alternative to human and cow milk for various clinical conditions such as allergy, atrophy and inflammatory diseases (Jirillo et al., 2010). The major proteins from cow milk are $\alpha \mathrm{S} 1$ - casein and $\alpha$-lactalbumin, whereas the major protein fraction of goat milk is composed of $\beta$-casein, $\alpha \mathrm{S} 2$-casein, and a small amount of $\alpha \mathrm{S} 1$-casein (Fisberg et al., 1999). Cow milk allergy is a common condition, affecting $5.7 \%$ of Brazilian children (Binsfeld et al., 2009) during the first 3 years of life and 12 to $30 \%$ of infants less than 3 month old, with frequencies as high as $20 \%$ in certain areas. The substitution of goat milk for cow milk is reported to re-solve between 30 and $40 \%$ of 
problem cases (Haenlein, 2004). In spite of the nutritional advantages, the market for goat milk and its derivatives is not yet fully recognize.

They have peculiar taste and nutritional properties and also recognized as a healthy food, goat milk has received special attention by researchers and dairy industry. Some properties of goat milk are known to be advantageous compared with those of sheep milk, such as higher tolerance by allergic children, which is related to the amount of and structural differences in whey proteins (a-lactalbumin and blactalbumin) and the high proportion of small fat globules $(1.5 \mathrm{~mm})$, which provide better digestibility (Haenlein, 2004; Raynal-Ljutovac et al., 2005). Furthermore, researchers have given goat milk a special attention after recognizing it as a potential functional food since it holds potential as a natural source of lactosederived oligosaccharides, present a healthier lipid composition with increased conjugated-linoleic acid and short fatty acids content and higher vitamin ( $\mathrm{A}$ and $\mathrm{B}$ complex) and calcium content (Park, 2006; Silanokove et al.,, 2010), which means that may provide a health bene? $t$ beyond its nutritional value. Despite the availability of scienti?c information about the positive aspects of the consumption of goat's milk and goat dairy products, the production of this milk in some countries is scarce (such as in Nigeria), limiting the production of goat dairy. Presently, there is no information on the consumption of goat milk in Odeda Local Government, Ogun State.

\section{Materials and methods}

This research was conducted in Odeda Local Government within Ogun State. A total of 70 respondents were interviewed using a well structured questionnaires administered to the residents of the area. Random sampling procedure was used in locations.

\section{Experimental animals}

Twenty-three (23) West African dwarf does were raised under semi-intensive management system at the Federal University of Agriculture Abeokuta, Nigeria. The goats were fed on concentrate and naturally synchronized by introducing WAD bucks into their midst hence, bringing them on heat at approximately the same time, after which they were mated. Their gestation period lasted for about 5 months. The milking process started a week after parturition. The milk was collected into a clean container and pasteurized at a temperature of $74^{\circ} \mathrm{C}$ for seven minutes and left for fifteen minutes to cool to a temperature of $40^{\circ} \mathrm{C}$. It was packaged in small polythene, sealed and refrigerated before taken to various rural settlement in Odeda Local Government of Ogun state for sensory evaluation.

\section{Data analysis}

The data collected were analyzed using descriptive analysis such as percentages and frequency count.

\section{Results and discussion \\ Socio-economic characteristics of respondent}

Table 1 shows the socio-economic characteristics of the respondent chosen at random (including both male and female). Majority of the respondents were students $54.3 \%$ only a few $12.9 \%$ were traders with a high percentage between the ages of 21-30. Also, $67.1 \%$ and $70.0 \%$ of the respondents were Christian and Yorubas, respectively. Moreover, $65.7 \%$ of respondents were married, while $34.3 \%$ were unmarried. The married had a family size of $0-2$. This implies that the respondents had sizeable family. Majority of the respondents 
Table 1: Socio-economic factors of the respondents

\begin{tabular}{|c|c|c|}
\hline Variables & Frequency & Percentage (\%) \\
\hline \multicolumn{3}{|l|}{ Occupation } \\
\hline Farming & 11 & 15.7 \\
\hline Trader & 9 & 12.9 \\
\hline Civil servant & 12 & 17.2 \\
\hline Student & 38 & 54.3 \\
\hline \multicolumn{3}{|l|}{ Age } \\
\hline$<10$ & - & - \\
\hline $10-20$ & 24 & 34.2 \\
\hline $21-30$ & 30 & 42.9 \\
\hline $31-40$ & 13 & 18.4 \\
\hline $41-50$ & 3 & 4.2 \\
\hline \multicolumn{3}{|l|}{ Religion } \\
\hline Islamic & 23 & 32.9 \\
\hline Christianity & 47 & 67.1 \\
\hline \multicolumn{3}{|l|}{ Tribe } \\
\hline Yoruba & 49 & 70 \\
\hline Igbo & 14 & 20 \\
\hline Hausa & 1 & 1.4 \\
\hline Fulani & 2 & 2.9 \\
\hline Igbira & 4 & 5.7 \\
\hline \multicolumn{3}{|l|}{ Marital status } \\
\hline Single & 46 & 65.7 \\
\hline Married & 24 & 34.3 \\
\hline \multicolumn{3}{|l|}{ Family size including children } \\
\hline $0-2$ & 36 & 51.4 \\
\hline $3-5$ & 29 & 41.5 \\
\hline $6-8$ & 5 & 7.2 \\
\hline \multicolumn{3}{|l|}{ Educational level } \\
\hline Secondary level & 5 & 7.1 \\
\hline Secondary school uncompleted & 3 & 4.3 \\
\hline Tertiary & 62 & 88.6 \\
\hline \multicolumn{3}{|l|}{ Any experience on ruminant farming } \\
\hline Yes & 26 & 37.1 \\
\hline No & 44 & 62.9 \\
\hline \multicolumn{3}{|l|}{ If yes, years of experience } \\
\hline $0-2$ & 47 & 67.2 \\
\hline $3-5$ & 18 & 25.7 \\
\hline $6-8$ & 4 & 5.7 \\
\hline $9-11$ & - & - \\
\hline $12-15$ & 1 & 1.4 \\
\hline \multicolumn{3}{|l|}{ Numbers of goat kept } \\
\hline $0-5$ & 64 & 91.4 \\
\hline $6-10$ & 3 & 4.3 \\
\hline $11-15$ & - & - \\
\hline $16-20$ & 1 & 1.4 \\
\hline $21-25$ & 1 & 1.4 \\
\hline $26-30$ & 1 & 1.4 \\
\hline
\end{tabular}

Source: Field Survey, 2015

(88.8\%) had tertiary education. High level of awareness about goat milk could be as a result of their level of education. This agrees with the findings of Adewumi et al. (2007) and Anosike et al. (2016). On the other hand, Apata and Adewumi (2011); Adewumi et al. (2015) reported that lack of awareness was the major reasons for the low consumption of small ruminant milk in Ekiti State. Education is a factor that 
influences the adoption of new technologies and development. The small number of respondents $37.1 \%$ had only 2 years ruminant farming experience and kept fewer than 5 goats. These goats were kept as hobby and not for any serious business.

Table 2 shows the frequency distribution of milk consumption. A high percentage of the respondents $(60 \%)$ consumed milk on weekly basis while $6 \%$ consumed milk on daily basis. This is consistent with the report of Adewumi et al. (2007). This has led a lot of implication on health and standard of living. The low intake of milk could probably be because of the high cost of available cow milk.

It was observed that $100 \%$ of the respondents preferred cow despite the fact that $62.9 \%$ of the respondent were aware of goat milk because $32.9 \%$ of the respondent believed that cow milk is readily available. Then it was observed that $78.6 \%$ of the respondents were aware that goat milk is consumable and that it can be an alternative to cow milk.

Table 2: Socio-economic factors influencing the consumption of milk

\begin{tabular}{lll}
\hline Variables & Frequency & Percentage (\%) \\
\hline How often do you drink milk & 6 & 8.6 \\
$\quad$ Daily & 61 & 87.1 \\
$\quad$ Weekly & 3 & 4.3 \\
$\quad$ Monthly & 11 & 15.7 \\
Which type of animal milk are you aware of & 44 & 62.9 \\
$\quad$ Cow milk & 1 & 1.4 \\
$\quad$ Goat milk & 14 & 20.0 \\
$\quad$ Sheep milk & & \\
Others & 70 & 100 \\
Out of the above, which one do you take & - & - \\
Cow milk & - & - \\
$\quad$ Goat milk & - & - \\
Sheep milk & & \\
Others & 23 & 32.9 \\
Reasons for the choice & 2 & 2.9 \\
It is readily available & 4 & 5.7 \\
It is cheap & 8 & 11.4 \\
It is more nutritious than other milk & - & - \\
I like the taste & - & - \\
I like the colour & 33 & 47.1 \\
I like the Odour & & \\
Others & & 78.6 \\
Are you aware that goat milk is consumable and & 55 & 21.4 \\
source of milk & 15 & \\
Yes & & \\
No & &
\end{tabular}

Source: Field Survey, 2015

Respondents' perception of goat milk consumption

As revealed in Table 3, it was noticed that respondents had positive perception towards the consumption of goat milk as $54.3 \%$ agreed that the colour of goat milk was whiter than that of the cow milk while $37.1 \%$ strongly agreed. Also, 52.9\% strongly disagreed that the texture of goat milk is coarse as particles while $28.6 \%$ of the respondents strongly agreed. It was observed that about $60 \%$ disagreed that goat 
milk was not palatable while $32.9 \%$ strongly disagreed. A total of $47.1 \%$ strongly disagreed that the body odour of goat could discourage the consumption goat milk, however, $32.9 \%$ disagreed. It was observed from the study that $64.3 \%$ strongly disagreed to the perception that children consuming goat milk behave like animals, while $2.9 \%$ strongly agreed. It was thus clear that goat milk was well accepted by residents of Odeda Local Government. It then become imperative for this positive perception to be explored by the government and other relevant development agencies so as to increase food supply to alleviate protein deficiency and thereby improves the economy. This finding is in agreement with that of Apata and Adewumi (2010). Furthermore, there was no cultural taboo as $61.4 \%$ strongly disagreed against the consumption of goat milk. This is consistent with the findings of Adewumi et al. (2001) who reported that there was no taboo to rearing of small ruminants and consumption of their milk in Ondo State.

Table 3: Respondents' perception of goat milk consumption

\begin{tabular}{|c|c|c|}
\hline Perceptional statement & frequency & Percentage \\
\hline \multicolumn{3}{|c|}{ The colour of a goat milk is whiter than cow's milk } \\
\hline Strongly agree & 26 & 37.1 \\
\hline Agree & 38 & 54.3 \\
\hline Strongly disagree & - & - \\
\hline Disagree & 1 & 1.4 \\
\hline Undecided & 5 & 7.1 \\
\hline \multicolumn{3}{|c|}{ The texture of the milk is coarse, containing particles in it } \\
\hline Strongly agree & 5 & 7.1 \\
\hline Agree & 5 & 7.1 \\
\hline Strongly disagree & 20 & 28.6 \\
\hline Disagree & 37 & 52.9 \\
\hline Undecided & 3 & 4.3 \\
\hline \multicolumn{3}{|c|}{ Goat milk is forbidden by the culture of the land } \\
\hline Strongly agree & - & - \\
\hline Agree & 1 & 1.4 \\
\hline Strongly disagree & 43 & 61.4 \\
\hline Disagree & 24 & 34.3 \\
\hline Undecided & 2 & 2.9 \\
\hline \multicolumn{3}{|l|}{ Goat milk is not palatable } \\
\hline Strongly agree & 2 & 2.9 \\
\hline Agree & 2 & 2.9 \\
\hline Strongly disagree & 23 & 32.9 \\
\hline Disagree & 42 & 60.0 \\
\hline Undecided & 1 & 1.4 \\
\hline \multicolumn{3}{|c|}{ Body odour of goat could discourage goat milk consumption } \\
\hline Strongly agree & 3 & 4.3 \\
\hline Agree & 8 & 11.4 \\
\hline Strongly disagree & 33 & 47.1 \\
\hline Disagree & 23 & 32.9 \\
\hline Undecided & 3 & 4.3 \\
\hline \multicolumn{3}{|c|}{ The colour of goat milk could be discouraging } \\
\hline Strongly agree & 1 & 1.4 \\
\hline Agree & 1 & 1.4 \\
\hline Strongly disagree & 29 & 41.4 \\
\hline Disagree & 34 & 48.6 \\
\hline Undecided & 5 & 7.1 \\
\hline \multicolumn{3}{|c|}{ Children consuming goat milk might be stubborn like goat } \\
\hline Strongly agree & 2 & 2.9 \\
\hline Agree & - & - \\
\hline Strongly disagree & 45 & 64.3 \\
\hline Disagree & 20 & 28.6 \\
\hline Undecided & 3 & 4.3 \\
\hline
\end{tabular}


Sensory evaluation of goat milk: percent distribution of respondent

Majority of the respondents had a favourable disposition towards the taste (75.5\%), colour $(62.9 \%)$, odour $(80.0 \%)$ and flavor $(61.4 \%)$ when compared with other milk products in the market (Table 4). This may be attributed to the freshness of the milk which corroborates the reports of Adewumi et al. (2001). This is in line with the findings of Adewumi et al. 2001 who reported that respondents had positive inclination towards small ruminant milk consumption. The good flavor of goat milk in some studies was reported to have originated from some free fatty acids such as 4-methyloctanoic acid and 4ethyloctanoic acid in goat (Morgan and Gaborit, 2001; Carunchia Whestine et al., 2003).

Table 4 : Respondent reaction to sensory characteristics of goat milk vs other milk products

\begin{tabular}{lll}
\hline Parameters & Frequency & Percentage \\
\hline Taste & 16 & 22.9 \\
$\quad$ Better than & 53 & 75.7 \\
$\quad$ Compares favourably & 1 & 1.4 \\
$\quad$ Compares unfavourably & 26 & 37.1 \\
Colour & 44 & 62.9 \\
$\quad$ Better than & - & - \\
$\quad$ Compares favourably & 8 & \\
$\quad$ Compares unfavourably & 56 & 11.4 \\
Odour & 6 & 80.0 \\
$\quad$ Better than & & 8.6 \\
$\quad$ Compares favourably & 25 & 35.7 \\
$\quad$ Compares unfavourably & 43 & 61.4 \\
Flavor & 2 & 2.9 \\
$\quad$ Better than & & \\
Compares favourably & Compares unfavourably &
\end{tabular}

Source: Field Survey, 2015

\section{References}

Adewumi, O. O., Ologun, A. G. and Alokan, J. A. 2001. Sensory evaluation and marketability of sheep milk in Akure. Journal of Agriculture, Forestry and Fisheries. 2:5-7.

Adewumi, O. O. 2005. Sheep milk. The most important but neglected sources of protein. Proceedings of the $10^{\text {th }}$ Annual Conference of Animal Science Association of Nigeria (ASAN), University of Ado-Ekiti, Nigeria, pg 237-239.

Adewumi, O. O. 2007. Socio-economic factors influencing milk consumption pattern in some selected local government areas of
Ekiti State. Applied Tropical Agriculture. 12:6-10.

Apata, O. M. and Adewumi, O. O. 2011. Perception of sheep and goat milk consumption among rural dwellers in South Western Nigeria. Nigerian Journal of Animal Production. 38:145-152.

Adewumi, O. O., Lawal-Adebowale, $\mathbf{O}$. A. and Adegbemile, D. A. 2015. Assessment of farm families' acceptability of small ruminants' milk for consumption in selected rural communities in Ogun State, Nigeria. International Journal of Agricultural Extension and Rural Development (JAERD). 7(4):135$1 \quad 4 \quad 1$ 
http:www.academicjournals.org/J AERD.

Anosike, F. U. and Owoshagba, O. B. 2016. Youth involvement in livestock production in Giwa Local Government Area of Kaduna State. Proceedings of the $41^{s t}$ Annual Conference of the Nigerian Society for Animal Production (NSAP), V.A. Aletor and G.E.Onibi (Eds.). 656-660.

Binsfeld, B. L., Pastorino, A. C., Castro, A. P. B. M., G. H. Yonamine, A. K. F. Gushken, and Jacob, C. M. A. 2009. Knowledge of industrialized dairy product labels by parents of patients allergic to cow's milk. Revista Paulista de Pediatria 27:296-302.

Bottero, M. T., Civera, T., Nucera, D., Rosati, S., Sacchi, P. and Turi, R. M. 2003. Multiplex polymerase chain reaction for the identification of cows', goats' and sheep's milk in dairy products. Int. Dairy J. 13:277-282.

Cartoni, G. P., Coccioli, F., Jasionowska, R. and Masci, M. 1998. Determination of cow milk in buffalo milk and mozzarella cheese by capillary electrophoresis of the whey protein fractions. Ital. J. Food Sci. 2:127-131.

Carunchia Whetstine, M. E., KaragulYuceer, Y., Avsar, Y. K. and Drake, M. A. 2003. Identification and quantification of character aroma components in fresh Chevre-style goat cheese. J. Food Sci. 68:2441-2447.

Egito, A. S., Rosinha, G. M. S., Laguna, L. E., Miclo, L., Girar- det, J. M. and. Gaillard, J. L. 2006. Método eletroforético rápido para detecção da adulteração do leite caprino com leitebovino. Arq.

Bras. Med. Vet. Zootec. 5:932-939.

Feligini, M., Bonizzi, I., Curik, V. C., Parma, P., Greppi G. F. and Enne, G. 2005. Detection of adulteration in Italian mozzarella cheese using mitochondrial DNA templates as biomarkers. Food Technol. Biotechnol. 43:91-95.

Fisberg, M., M. Nogueira, A. Ferreira, and Fisberg. R. M. 1999. Aceitação e tolerância do leite de cabra em pré-escolares. Pediatr. Mod. 7:526-530.

Guo, M., Park, Y. W., Dixon, P. H., Gilmore, J. A. and Kindstedt, P. S., 2004. Relationship between the yield of cheese (chevre) and chemical composition of goat milk. Small ruminants Res. 52, 103-107.

Haenlein, G. F. W. 2004. Goat milk in human nutrition. Small Rumin. Res. 51:155-163.

Jirillo, F., Jirillo, E. and Magrone, T. 2010. Donkey's and goat's milk consumption and benefits to human health with special reference to the inflammatory status. Curr. Pharm. Des. 16:859-863.

Kaminarides, S. E. and Anifantakis, E. M. 1993. Comparative study of the separation of casein from bovine, ovine and caprine milks using HPLC. J. Dairy Res. 60:495-504.

Law, A. J. R. and Tziboula, A. 1992. Quantitative fractionation of caprine casein by catione x c h a n g e F P L C . Milchwissenschaft 47:558-562.

Mašková, E. and Paulípková, I. 2006. PCR-based detection of cow's milk in goat and sheep cheeses 
marketed in the Czech Republic. Czech J. Food Sci. 24:127-132.

Meilgaard, M. C., Civille, G. V. and Carr. B. T. 1991. Sensory Evaluation Techniques. 2nd ed. CRC Press, Boca Raton, FL.

Morgan, F. and Gaborit, P. 2001. The typical flavor of goat milk products: Technological aspects. Int. J. Dairy Technol. 54:38-40.

Park, Y. W., Haenlein, G. F. W. 2006. Goat milk, its product and nutrition. In: Hui, Y.H.(Ed.), Handbook of food products manufacturing. John wiley, New York, NY.

Payne, W. J. A. 1990. An introduction to Animal Husbandry in the tropics, Longman group UK Ltd $4^{\text {th }}$ edition. Posati, L.P., Orr, M.L., 1976. Composition of Foods. ARS, USDA, Washington, DC (Agric. Handbook No. 8-1).
Raynal-Ljutovac, K., Gaborit, P. and Lauret, A. 2005. The relationship between quality criteria of goat milk, its technological properties and the quality of the final products. Small Ruminant Research, 60, 2005, pp. 167-177.

Silanikove, N., Leitner, G., Merin, U. and Prosser, C. G. 2010. Small Rumin. Res. 89 (2-3). 110-124. Skjevdal, T. 1979. Flavour of goat's milk. A review of studies on the sources of variations. Livest. Prod. Sci. 6:397-405.

Received: $11^{\text {th }}$ November, 2017

Accepted: $20^{\text {th }}$ February, 2018 